\title{
SISTEM INFORMASI PENJUALAN KAIN ULOS \\ PADA PARULIAN ULOS
}

\author{
Oleh : \\ Irfan Nasrullah \\ Program Study Teknik Informatika Fakultas Teknik \\ Universitas Muhammadiyah Tangerang \\ E-mail:pengembara82@yahoo.co.id
}

\begin{abstract}
ABSTRAK
Parulian Ulos adalah toko yang mengkhususkan penjualan Kain Ulos di Pematang Siantar, Sumatera dan saat ini bekerja untuk mengembangkan usahanya. Dengan toko-toko yang tersebar di Pemantang Siantar tidak cukup untuk menjangkau konsumen luar daerah dan luar pulau. Untuk menjangkau daerah-daerah di luar Pematang Siantar, mendirikan toko akan biaya banyak dan juga kebutuhan biaya tenaga kerja lebih juga. Lainnya kendala yang muncul dengan berdirinya toko besar adalah kapasitas dari toko yang digunakan untuk menyimpan dan menampilkan stok produk terbatas. berdasarkan uraian di atas, maka perlu diciptakan suatu sistem sistem informasi penjualan Kain Ulos berbasis web yang dapat membantu pemilik usaha Parulian Ulos. Parulian Ulos untuk memperluas area pemasaran produknya. Pemilik tidak perlu menguras banyak uang untuk mendanai staf tambahan, cukup untuk menutupi seseorang untuk mengelola atau admin ke website pemeliharaan. Website yang memungkinkan toko untuk menampilkan produk yang lebih dari kemampuan untuk mendirikan toko.
\end{abstract}

\section{Kata Kunci : Sistem Informasi Penjualan, Kain Ulos}

\section{PENDAhUluan}

Parulian Ulos adalah sebuah perusahaan yang bergerak di bidang bisnis Tekstil yaitu pembuatan kain Ulos di Pematang Siantar Sumatera Utara. Pada saat ini persaingan bisnis tekstil bukan hanya dipengaruhi oleh faktor harga, akan tetapi lebih mengarah pada persaingan dalam memberi pelayanan yang terbaik pada setiap pembeli (customer).

Pada saat ini penyimpanan, pengelolaan, pemeliharaan data dan informasi tentang pembeli (customer) yang terdapat pada Parulian Ulos masih dalam bentuk arsip atau berkas fisik. Apabila dilihat dari sisi efisiensi kerja tentu saja hal ini membuat operasional terkesan kurang handal dan memiliki banyak resiko, karena berkas-berkas ini bersifat tidak permanen, mudah rusak dan jika rusak tidak terdapat data cadangan, selain itu data administrasi pembeli (customer) ini juga tidak dapat diakses secara langsung oleh pengguna sehingga memerlukan waktu dan tenaga serta biaya.

Peningkatan kualitas layanan di Parulian Ulos memerlukan pengaturan data secara terintegrasi pada Bagian Penjualan sebagai pengolah transaksi dengan pengambil keputusan oleh pemilik (owner) sebagai pihak yang berkepentingan dalam pengelolaan data dan transaksi pembeli (customer). Salah satu cara yang bisa diterapkan adalah penggunaan sistem yang dapat menyebarkan informasi mengenai pelanggan yakni aplikasi pengelolaan data pembeli (customer) dan transaksi penjualan. Aplikasi tersebut merupakan media atau alat yang digunakan untuk mengelola, menyimpan dan memelihara data pembeli (customer) dan transaksi dalam perusahaan untuk meningkatkan keunggulan dalam hal pelayanan yang diberikan pada pembeli (customer) dalam bentuk sebuah aplikasi. 


\section{LANDASAN TORI}

\section{Penjualan}

Konsep penjualan adalah gagasan bahwa konsumen tidak akan membeli cukup banyak produk perusahaan kecuali jika perusahaan tersebut melakukan usaha penjualan dan promosi dalam skala besar.

Menurut Kotler (2006:457), penjualan merupakan sebuah proses dimana kebutuhan pembeli dan kebutuhan penjualan dipenuhi, melalui antar pertukaran informasi dan kepentingan. Jadi konseppenualan adalah cara untuk mempengaruhi konsumen untuk membeli produk yang ditawarkan. Dalam kenyataannya penjualan mempunyai dua sistem yang biasa diterapkan oleh suatu perusahaan dagang yaitu penjualan yang dilakukan dengan cara tunai dan penjualan yang dilakukan menggunakan cara kredit atau sering disebut cara angsuran.

Penjualan yang dilakukan secara tunai merupakan penjualan dimana saat terjadi penjualan pembeli akan membayar harga barang atau jasa yang dibelinya saat itu juga. Penjualan yang dilakukan secara kredit atau angsuran adalah bilamana pembayaran baru diterima beberapa waktu kemudian setelah terjadinya transaksi penjualan dan cara pembayarannya dapat dilakukan secara bertahap dengan jumlah tertentu dan dalam jangka waktu tertentu pula.

Pentingnya promosi penjualan karena promosi penjualan adalah kegiatan-kegiatan pemasaran selain personal selling, periklanan dan publisitas, yang mendorong evektifitas pembelian konsumen dan pedagang dengan menggunakan alat peragaan, pameran, demonstrasi, dan sebagainya yang ditunjukkan untuk meningkatkan penjualan barang tertentu.

\section{Sistem Informasi}

Sistem informasi adalah suatu sistem di dalam suatu organisasi yang mempertemukan kebutuhan pengolahan transaksi harian, mendukung operasi bersifat manejerial dan kegiatan strategi dari suatu organisasi dan menyediakan pihak luar tertentu dengan laporan-laporan yang diperlukan (Yogiyanto, 1989). Menurut Simkin Mark G dalam bukunya yang berjudul computer information system for business, system informasi adalah sekumpulan elemen yang bekerja secara bersama-sama baik secara manual ataupun berbasis computer dalam melaksanakan pengolahan data yang berupa pengumpulan, penyimpanan, pemrosesan data untuk menghasilkan informasi yang bermakna dan berguna bagi proses pengambilan keputusan.

\section{Sistem Infomasi Penjualan}

Menurut Kolter (1999 : 100) sistem informasi penjualan merupakan suatu sistem yang terdiri dari kumpulan orang, peralatan dan prosedur yang memadukan antara pekerjaan mesin (komputer) dan manusia yang menyajikan keakuratan informasi bagi para pemakai dalam membuat keputusan untuk memecahkan masalah didalam perusahaan.

\section{Website}

Website adalah sebutan untuk sekelompok halaman web (web page), yang pada umumnya merupakan bagian dari suatu nama domain atau sub domain di World Wide Web di Internet. WWW terdiri dari seluruh situs web yang tersedia kepada public. Halaman-halaman sebuah situs web diakses dari sebuah URL yang menjadi akar (root), disebut dengan homepage (halaman induk atau halaman muka) dan pada umumnya disimpan pada server yang sama. Sebuah website biasanya dibuat oleh individual, bisnis atau organisasi berdasarkan topic dan tujuan tertentu. Setiap website dapat juga berisi hyperlink ke website lainnya, jadi antara satu wesite dengan website lainnya dapat saling berhubungan.

Website ditulis atau dirubah secara dinamis menjadi HTML (Hyper Text Markup Language) dan diakses dengan menggunakan software yang disebut Internet Browser yang dikenal juga dengan sebutan HTTP client. Web page dapat diakses dan dilihat dari berbagai macam alat, diantaranya desktop computer, laptop computer, PDA ataupun cell phone yang semuanya mempunyai koneksi internet. Sebuah website ditampung dalam sebuah sistem computer yang disebut web-server, dikenal juga dengan sebutan HTTP server. Server ini menggunakan software yang berfungsi dan mengirim respon web page terhadap perintah yang dilakukan oleh pengakses website.

Ada dua jenis website yang ada saat ini, yaitu Static Website dan Dynamic Website. Dua-duanya memiliki kelebihan dan kekurangan masing-masing. Dibawah ini akan dijelaskan beberapa pengertian dari Static Website dan Dynamic Website. Static website (Website Statis) adalah website yang isinya dirancang untuk sering berubah secara manual, dan biasanya dikelola perorangan dengan menggunakan beberapa software editor.

Dynamic Website (Website Dinamis) adalah website yang isinya dan informasinya dirancang untuk 
sering berubah. Ketika web-server menerima perintah untuk menampilkan sesuatu dalam web-page, maka web-page akan secara otomatis digerakkan oleh software yang dipakai untuk segera merespon perintah tersebut, contohnya: website dapat menampilkan status dialog antar user, memonitor situasi yang terjadi atau menyediakan informasi yang diminta oleh individual user. Beberapa sistem software yang dapat digunakan untuk enunjang dalam pembuatan Dynamic Website antara lain : PHP, ASP.NET dan JSP.

\section{ANALISA PERANCANGAN SISTEM}

\section{- Dokumen Flow Transaksi Penjualan}

Dokumen flow adalah sebuah model yang disusun sesuai dengan proses bisnis yang ada yang akan dibangun menjadi sebuah sistem yang baru. Dokumen flow ini akan digunakan oleh analis sistem untuk memahami proses bisnis dan aliran dokumen yang ada untuk kemudian dianalisa dan dirancang kembali sistem yang akan digunakan. Pada dokumen flow dibawah ini menjelaskan bagaimana alur proses penjualan. Proses diawali dengan pencarian produk pada gudang untuk didisplay pada toko. Setelah itu maka akan keluar produk yang dipilih untuk didisplay beserta katalog produk yang tersedia. Proses selanjutnya yaitu didisplay produk pada toko agar dapat dilihat oleh pembeli. Apabila setelah melihat didisplay produk pembeli berminat dengan produk yang ditampilkan, maka dilanjutkan pemesanan produk oleh pembeli, kemudian Pemilik Parulian Ulos membuat nota penjualan yang nantinya diserahkan kepada pembeli. Data produk yang keluar dicatat secara manual oleh Parulian Ulos. Laporan transaksi berupa nota penjualan akan digunakan sebagai bukti transaksi sebagai pertanggung jawaban Parulian Ulos terhadap produk yang berhasil dijual kepada pemilik Parulian Ulos. Setelah melakukan pembuatan nota penjualan, maka produk yang dipesan diserahkan kepada pelanggan beserta nota penjualan. Dari hasil transaksi penjualan pemilik Parulian Ulos akan melihat laporan penjualan yang nantinya akan digunakan untuk menentukan keputusan penjualan berikutnya.

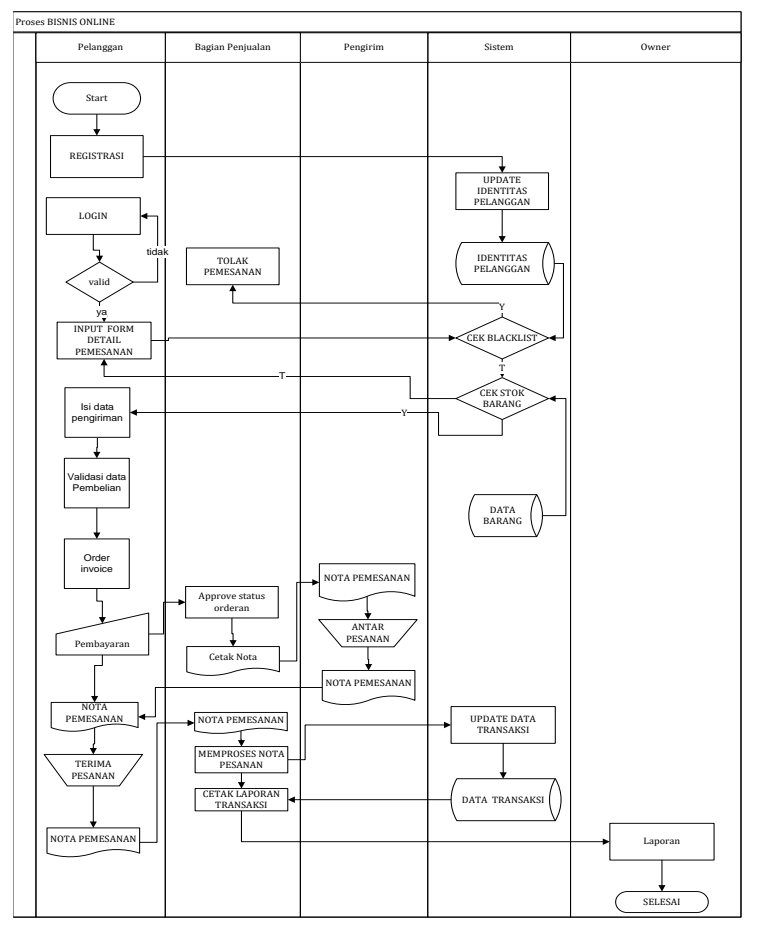

Gambar 1 Flow Transaksi Penjualan

\section{- Context Diagram}

Context diagram dari sistem informasi ini seperti digambarkan pada gambar di bawah ini.

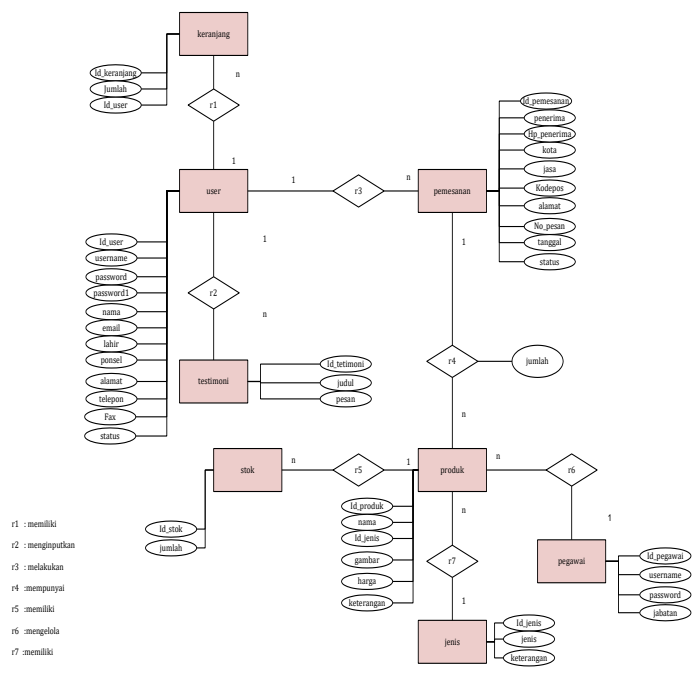

Gambar 2 Context Diagram

Dari context diagram diatas maka di break down ke level 0 untuk melihat proses lebih detail lagi seperti gambar dibawah ini :

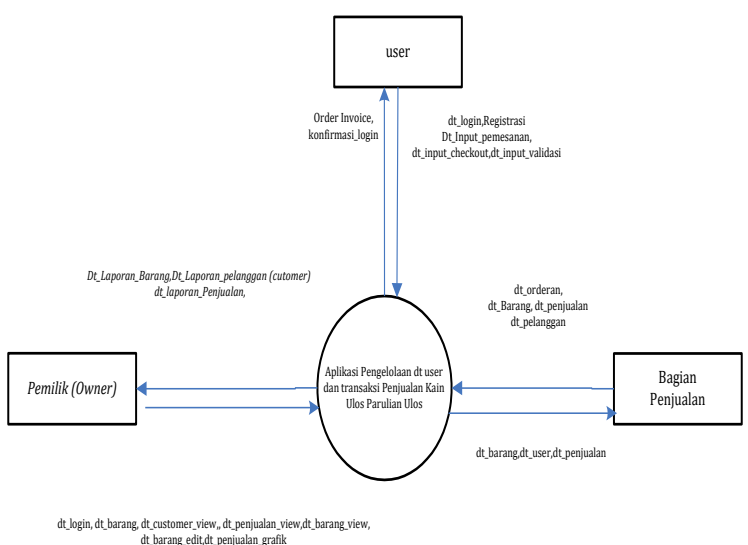


Gambar 3 DFD Level 0

\section{- Conceptual Data Model}

Sebuah Conceptual Data Model menggambarkan secara keseluruhan konsep struktur basis data yang dirancang untuk suatu program atau aplikasi.

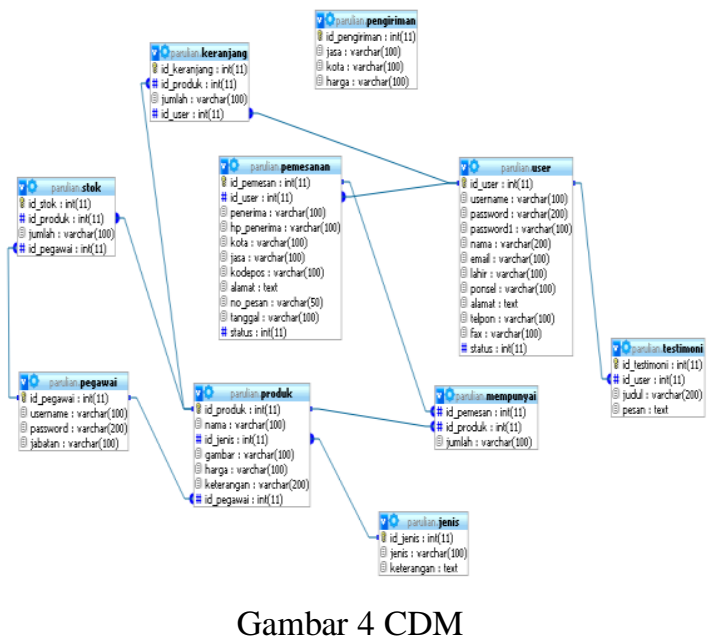

\section{HASIL DAN PEMBAHASAN}

Dalam pembuatan program aplikasi ini, penulis akan mengerjakan tahap-tahap secara berurutan, sesuai dengan ketentuan yang ada agar dapat memudahkan dalam pembuatan program.

\section{- Halaman Home}

Pada halaman pembuka terdapat halaman home dan teks dimana dalam halaman tersebut terdapat menu pilihan.

Berikut ini adalah gambar dari perancangan program pada halaman pembuka yang telah penulis diatas.

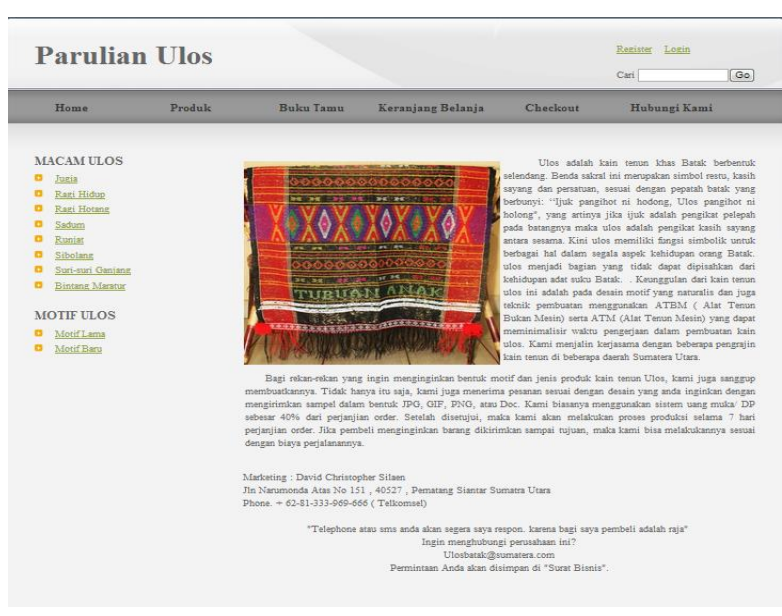

Gambar 5 Perancagnan Halaman Home

- Pendaftaran Customer

Pendaftaran customer dengan

meninputkan email, password, konfirmasi password, nama, alamat, kota, telp, dan kodepos kemudian daftar

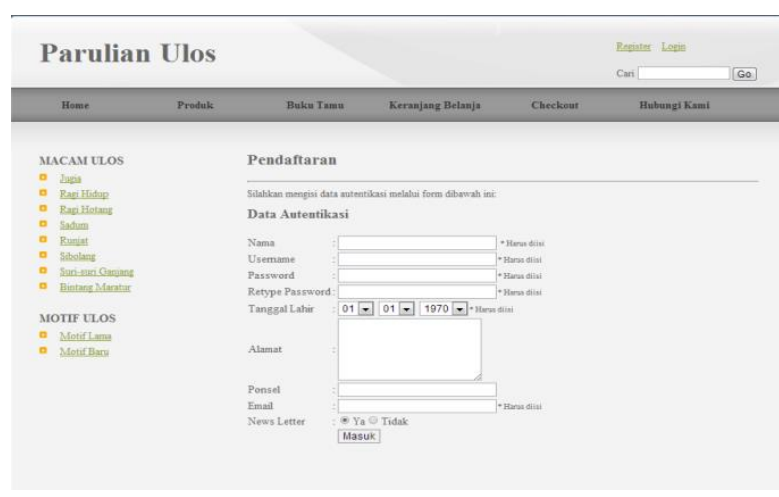

Gambar 6 Proses Registrasi Customer

- Pemesanan Produk

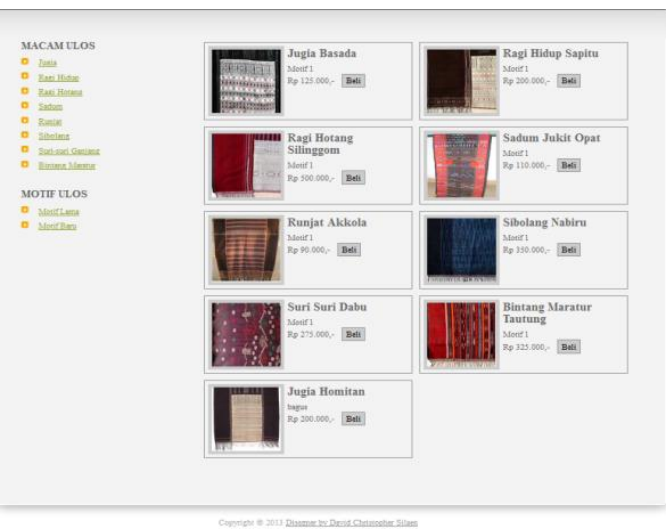

Gambar 6 Proses Pemesanan Produk

\section{- Keranjang Belanja}

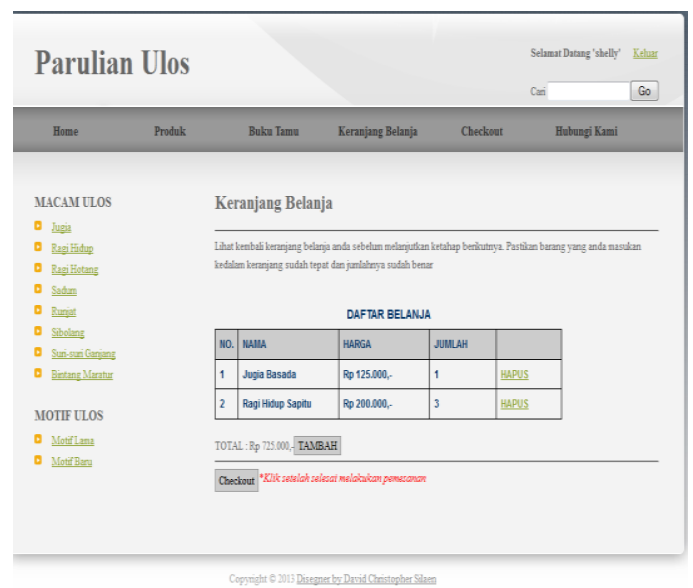


Gambar 7 Proses Keranjang Belanja

\section{Kesimpulan}

Dengan pembangunan aplikasi pengelolaan data pelanggan dan transaksi penjualan kain ulos pada skripsi ini dapat membantu kinerja perusahaan pada bagian penjualan dan Pemilik (owner) dalam melayani pelanggan yang memiliki fungsionalitas sebagai berikut:

a) Dengan adanya sistem informasi penjualan berbasis web ini mempermudah calon pelanggan untuk membeli produk - produk yang mereka inginkan tanpa harus mendatangi langsung Parulian Ulos.

b) Terdapat pengelolahan data barang, orderan dan pelanggan yang dapat menyampaikan informasi secara cepat dan real.

c) Tedapat laporan, penjualan pelanggan, laporan barang oleh pemilik (owner) sebagai tolah ukur pengembangan kinerja perusahaan untuk kemajuan perusahaan demi memberikan pelayanan yang terbaik bagi pelanggan.

\section{DAFTAR PUSTAKA}

Bodnar, George H., dan William S. Hopwood. "Flowchart." Dalam Accounting Information Systems, oleh George H. Bodnar and William S. Hopwood. 1993.

H.Hanny Ronosulistyo, dr., Sp. OG(K)., MM. RSUD AL IHSAN. bandung, 2010.

Hendraputra, ade. Perancangan Basis Data Relasional. Bandung: Telkom Polytechnic, 2009.

Heryanto, Iman. Menguasai Oracle, SQL dan PL/SQL . Bandung: Informatika Bandung, 2009.

Nugroho, Bunafit. Database Relational dengan MySQL. yogyakarta: Andi, 2004.

Presetyo, Eddy Nugroho, and Dkk. Rekayasa Perangkat Lunak. Bandung: Polytechnic Telkom, 2009.

Sahabat, Tim Redaksi Forum. BUKU PINTAR Pengadaan Barang \& Jasa Pemerintah. Jakarta: Forum Sahabat, 2011.

Saputra, Agus. Membangun Aplikasi Sms dengan PHP dan Mysql. Jakarta: PT Elex Media Komputindo, 2011.

Sidik, Betha, dan Husni Iskandar Pohan. pemrograman $W E B$ dengan HTML. Bandung: Informatika Bandung, 2009.

Petrus Pardede, Pembangunan Aplikasi Pengolahan Data Pelanggan Data Transaksi Data Transaksi Penjualan Berbasis Web, Telkom Bandung, 2011. 